\title{
Friends and Relaxation: Key Factors of Undergraduate Students' WeChat Using
}

\author{
Chun Mao \\ School of Journalism and Communication, Southwest University, Chongqing, China \\ Email: maochun1981@hotmail.com
}

Received 21 March 2014; revised 21 April 2014; accepted 29 April 2014

Copyright (C) 2014 by author and Scientific Research Publishing Inc.

This work is licensed under the Creative Commons Attribution International License (CC BY). http://creativecommons.org/licenses/by/4.0/

(c) (i) Open Access

\section{Abstract}

This paper aims to study the factors of undergraduate students' WeChat using, and adopts the structure of close-ended and the Likert-scale five-point measure questionnaire. We choose 200 undergraduate students as the respondents, randomly from different majors and grades. The result indicates: 1) almost all of the respondents use WeChat every day, and $18.8 \%$ of them use WeChat more than 2 hours per day. 2) The influence of friends is a major factor in using WeChat among undergraduate students. The item "Most of my friends use WeChat and encourage me to use" and "WeChat helps me to keep in touch with friends" recorded the highest and second highest mean score $(4.03 ; 3.97) .3)$ WeChat is a good way to release stress and relaxation for undergraduate students. It brings them more laughter and joy. 4) Family has no significant influence on WeChat using, and only $10 \%$ of the respondents agree with the item "I often chat with strangers in WeChat".

\section{Keywords}

WeChat, Undergraduate Students, Friends, Relaxation

\section{Introduction}

WeChat (Chinese pinyin: Wēixìn; literally "micro message”) is a mobile communication tool developed by Tencent in China, first released in January 2011, claimed "the new way to connect" and "a way of life". It is available for almost all kinds of mobile platforms, such as iPhone, Android, Windows Phone, Symbian, BlackBerry platforms and so on. It's free to download, install and use. WeChat enjoys group chat, supports sending voice, photo, video and text message. It also supports social networking via shared streaming content feeds and location-based social plug-ins ("shake”, "look around”, “drift bottle” and "Facebook connect”) to chat with and connect with other WeChat users. 
According to "The $33^{\text {rd }}$ Statistical Report on Internet Development in China” released by China Internet Network Information Center (CNNIC, 2014), by the end of December 2013, China has had 500 million mobile Internet users, 80 million more than that at the end of 2012. Mobile instant messaging has the largest number of mobile Internet users, accounted for $86.1 \%$. At the same time, the number of microblog users had reduced to 281 million, $37.4 \%$ of the microblog users shifted to WeChat; the number of users of social networking websites had reduced to 278 million, $32.6 \%$ of the social networking websites users shifted to WeChat. According to Tencent's report, the combined MAU (monthly activated users) of Weixin and WeChat reached 355 million at the end of December 2013 (Tencent, 2014).

The using of social networking sites and message apps has been a hot research topic in new media research. Social networking sites and message apps have been more and more popular in mobile users, for chatting, recording, showing, expressing, venting and so on (Lin et al., 2011; Karpinski et al., 2013; Gao et al., 2013). Researches on WeChat are mainly from China. Zhan and Yan (2013) find that WeChat's influence on network interpersonal communication is more apparent than real, and most of the users use WeChat to maintain and promote the relationship of acquaintance. Some researchers (Xiao et al., 2013; Bai et al., 2013) claim that WeChat is evolving from a pure message tool into a multi-functional platform, such as Game Center, Official Accounts and Payment. At the same time, WeChat has been introduced into education, to improve teaching and learning, such as mobile learning, blending learning, ideological education, and so on (Yuan et al., 2012; Li, 2013; Bai \& Hao, 2013). But few studies have addressed on factors of undergraduate students' WeChat using.

This paper aims to study the factors of undergraduate students' WeChat using. Descriptive statistics show that almost all of the respondents use WeChat every day. According to the Likert-scale five-point measure questionnaire, the influence of friends is a major factor in using WeChat among undergraduate students, and WeChat is a good way to release stress and relaxation for undergraduate students.

\section{Methodology}

This study aims to study the factors of undergraduate students' WeChat using, and adopts the structure of closeended and the Likert-scale five-point measure questionnaire. Each item is given a 5-point scale with $1=$ strongly disagree, 2 = disagree, 3 = slightly agree, 4 = agree, and 5 = strongly agree. Each questionnaire took 20 - 25 minutes to complete. The questionnaire was developed in Chinese. We chose 200 undergraduate students as the respondents. All of them came from Southwest University, and Chongqing Youth Vocational and Technical College. The questionnaires were randomly delivered to students from different majors and grades. Data for the research were collected for 2 weeks. We recalled 189 questionnaires, and selected the effective questionnaires according with the following criteria. 1) All of the questions are answered. 2) There is no inconsistent answer. After rejecting invalid questionnaires, there are 181 questionnaires available.

\section{Results}

\subsection{Descriptive Statistics}

The descriptive statistics of the respondents are shown in Table 1. The result of item "first time of using WeChat" shows that more than $90 \%$ of the respondents have used WeChat 6 months ago. Furthermore, there are 27 respondents (14.9\%) have used WeChat 2 years ago. According to the item "using frequency of WeChat", WeChat has been becoming an indispensable tool of undergraduate students' lives. All of the respondents are using WeChat. Most of the respondents (more than $84 \%$ ) use WeChat more than 30 minutes per day. Especially, 34 respondents (18.8\%) use WeChat more than 2 hours per day.

\subsection{Factors Affecting the WeChat Using of Undergraduate Students}

Table 2 displays the results of statements regarding factors about undergraduate students' WeChat using. There are 12 items in this research, and each item has five options. The mean score for each item was used to describe the strength of each item. According to the assignment of each option $(1=$ strongly disagree, $2=$ disagree, $3=$ slightly agree, 4 = agree, and $5=$ strongly agree), if the options have been divided equally, the mean score would be 3 .

In Table 2, there are 9 items' mean scores higher than 3, accounts for more than $81.8 \%$ of the total. Especially, 1 items' mean score is higher than 4 . On the other hand, there are 2 items' mean scores lower than 3 . The 
Table 1. Descriptive statistics of the respondents about WeChat using.

\begin{tabular}{cccc}
\hline Items & Options & $\begin{array}{c}\text { Number of people } \\
\text { (the total is 181) }\end{array}$ & $\begin{array}{c}\text { Percentage } \\
\text { (the total is 181) }\end{array}$ \\
\hline \multirow{2}{*}{ Gender } & Male & 94 & $51.9 \%$ \\
& Female & 87 & $48.1 \%$ \\
First time of using WeChat & Never & 0 & $0 \%$ \\
& Less than 6 months & 18 & $9.9 \%$ \\
& 6 - 12 months & 83 & $45.9 \%$ \\
Using frequency of WeChat & 1 - 2 years & 53 & $29.3 \%$ \\
& More than 2 years & 27 & $14.9 \%$ \\
& Never & 0 & $0 \%$ \\
& Less than 30 minutes per day & 26 & $14.4 \%$ \\
& 30 - 60 minutes per day & 52 & $28.7 \%$ \\
& $1-2$ hours per day & 69 & $38.1 \%$ \\
\end{tabular}

Table 2. Percentage distribution of factors about undergraduate students’ WeChat using.

\begin{tabular}{|c|c|c|c|c|c|c|}
\hline Item & $\begin{array}{c}\text { Strongly } \\
\text { disagree (\%) }\end{array}$ & Disagree (\%) & $\begin{array}{l}\text { Slightly } \\
\text { agree (\%) }\end{array}$ & Agree (\%) & $\begin{array}{l}\text { Strongly } \\
\text { agree (\%) }\end{array}$ & Mean \\
\hline $\begin{array}{l}\text { The using experience of WeChat } \\
\text { is better than expected. }\end{array}$ & $\begin{array}{l}3 \\
1.7 \%\end{array}$ & $\begin{array}{c}17 \\
9.4 \%\end{array}$ & $\begin{array}{c}77 \\
42.5 \%\end{array}$ & $\begin{array}{c}60 \\
33.1 \%\end{array}$ & $\begin{array}{c}24 \\
13.3 \%\end{array}$ & 3.47 \\
\hline $\begin{array}{l}\text { I feel satisfied that WeChat } \\
\text { meets my needs. }\end{array}$ & $\begin{array}{c}1 \\
0.6 \%\end{array}$ & $\begin{array}{c}15 \\
8.3 \%\end{array}$ & $\begin{array}{c}61 \\
33.7 \%\end{array}$ & $\begin{array}{c}76 \\
42.0 \%\end{array}$ & $\begin{array}{c}28 \\
15.5 \%\end{array}$ & 3.64 \\
\hline $\begin{array}{l}\text { WeChat helps me to keep in } \\
\text { touch with friends. }\end{array}$ & $\begin{array}{c}0 \\
0.0 \%\end{array}$ & $\begin{array}{c}8 \\
4.4 \%\end{array}$ & $\begin{array}{c}42 \\
23.2 \%\end{array}$ & $\begin{array}{c}78 \\
43.1 \%\end{array}$ & $\begin{array}{c}53 \\
29.3 \%\end{array}$ & 3.97 \\
\hline $\begin{array}{l}\text { WeChat allows me to make more friends, } \\
\text { to expand the circle of communication. }\end{array}$ & $\begin{array}{c}7 \\
3.9 \%\end{array}$ & $\begin{array}{c}30 \\
16.6 \%\end{array}$ & $\begin{array}{c}75 \\
41.4 \%\end{array}$ & $\begin{array}{c}51 \\
28.2 \%\end{array}$ & $\begin{array}{c}18 \\
9.9 \%\end{array}$ & 3.24 \\
\hline I often chat with strangers in WeChat. & $\begin{array}{c}43 \\
23.8 \%\end{array}$ & $\begin{array}{c}72 \\
39.8 \%\end{array}$ & $\begin{array}{c}48 \\
26.5 \%\end{array}$ & $\begin{array}{c}15 \\
8.3 \%\end{array}$ & $\begin{array}{c}3 \\
1.7 \%\end{array}$ & 2.24 \\
\hline $\begin{array}{l}\text { WeChat plays a significant role } \\
\text { for me to obtain information. }\end{array}$ & $\begin{array}{l}3 \\
1.7 \%\end{array}$ & $\begin{array}{c}17 \\
9.4 \%\end{array}$ & $\begin{array}{c}84 \\
46.4 \%\end{array}$ & $\begin{array}{c}66 \\
36.5 \%\end{array}$ & $\begin{array}{c}11 \\
6.1 \%\end{array}$ & 3.36 \\
\hline $\begin{array}{l}\text { WeChat brings me more } \\
\text { laughter and joy. }\end{array}$ & $\begin{array}{c}4 \\
2.2 \%\end{array}$ & $\begin{array}{c}13 \\
7.2 \%\end{array}$ & $\begin{array}{c}59 \\
32.6 \%\end{array}$ & $\begin{array}{c}74 \\
40.9 \%\end{array}$ & $\begin{array}{c}31 \\
17.1 \%\end{array}$ & 3.64 \\
\hline $\begin{array}{l}\text { WeChat is a good way to release } \\
\text { stress and relax myself. }\end{array}$ & $\begin{array}{c}0 \\
0.0 \%\end{array}$ & $\begin{array}{c}8 \\
4.4 \%\end{array}$ & $\begin{array}{c}43 \\
23.8 \%\end{array}$ & $\begin{array}{c}84 \\
46.4 \%\end{array}$ & $\begin{array}{c}46 \\
25.4 \%\end{array}$ & 3.93 \\
\hline $\begin{array}{l}\text { The majority of my classmates uses } \\
\text { WeChat and encourages me to use. }\end{array}$ & $\begin{array}{c}0 \\
0.0 \%\end{array}$ & $\begin{array}{c}18 \\
9.9 \%\end{array}$ & $\begin{array}{c}77 \\
42.5 \%\end{array}$ & $\begin{array}{c}50 \\
27.6 \%\end{array}$ & $\begin{array}{c}36 \\
19.9 \%\end{array}$ & 3.57 \\
\hline $\begin{array}{l}\text { Most of my friends use WeChat } \\
\text { and encourage me to use. }\end{array}$ & $\begin{array}{c}0 \\
0.0 \%\end{array}$ & $\begin{array}{c}14 \\
7.7 \%\end{array}$ & $\begin{array}{c}32 \\
17.7 \%\end{array}$ & $\begin{array}{c}70 \\
38.7 \%\end{array}$ & $\begin{array}{c}65 \\
35.9 \%\end{array}$ & 4.03 \\
\hline $\begin{array}{l}\text { My family uses WeChat and } \\
\text { encourages me to use. }\end{array}$ & $\begin{array}{c}32 \\
17.7 \%\end{array}$ & $\begin{array}{c}76 \\
42.0 \%\end{array}$ & $\begin{array}{c}52 \\
28.7 \%\end{array}$ & $\begin{array}{c}18 \\
9.9 \%\end{array}$ & $\begin{array}{l}3 \\
1.7 \%\end{array}$ & 2.36 \\
\hline
\end{tabular}

item "Most of my friends use WeChat and encourage me to use" recorded the highest mean score $(\mathrm{M}=4.03)$. The second highest mean score is "WeChat helps me to keep in touch with friends" ( $\mathrm{M}=3.97)$, followed by "WeChat is a good way to release stress and relax myself" $(\mathrm{M}=3.93)$ and "feel satisfied that WeChat meets my needs" ( $M=3.64)$. The lowest mean score is the item "I often chat with strangers in WeChat" $(M=2.24)$. The second lowest mean score is "My family uses WeChat and encourages me to use" $(\mathrm{M}=2.36)$. 


\section{Discussion}

Based on the results obtained above, most of the undergraduate students are satisfied with WeChat because using experience of WeChat is better than expected and meets their communication need. Almost all of the respondents use WeChat every day, and $18.8 \%$ of them use WeChat more than 2 hours per day. This may be considered as mild addiction and needs for attention.

The influence of friends is a major factor in using WeChat among undergraduate students. This is based that all of the items relate to friends had recorded high mean scores, such as "Most of my friends use WeChat and encourage me to use" ( $\mathrm{M}=4.03)$, "WeChat helps me to keep in touch with friends" $(\mathrm{M}=3.97)$, "WeChat allows me to make more friends, to expand the circle of communication" $(M=3.24)$. On the contrast, only $10 \%$ of the respondents agree with the item "I often chat with strangers in WeChat" (1.7\% strongly agree, $8.3 \%$ agree, $\mathrm{M}=$ 2.24).

In addition, classmates can also influence the use of WeChat among undergraduate students. Only $9.9 \%$ of the respondents disagree with the item "The majority of my classmates uses WeChat and encourages me to use" ( $0 \%$ strongly disagree, $9.9 \%$ disagree, $\mathrm{M}=3.57$ ). This may be because classmates compose a community and have shared experience. They study and live together every day, have same courses and similar schedule, even similar goals.

Encouragements from family have no significant contributing to the use of WeChat among undergraduate students. Only $11.6 \%$ of the respondents agree with the item "My family uses WeChat and encourages me to use" (1.7\% strongly agree, $9.9 \%$ agree), and it recorded the second lowest mean score $(M=2.36)$. Although the service of WeChat is based on acquaintance network, but this result emphasizes the core of undergraduate students' WeChat using is friend (or classmate) instead of acquaintance or family.

The results also show that $71.8 \%$ of respondents agree with the item "WeChat is a good way to release stress and relax myself" ( $25.4 \%$ strongly agree, $46.4 \%$ agree, $\mathrm{M}=3.93$ ), which recorded the third highest mean score of all the items; $58 \%$ agree with the item "WeChat brings me more laughter and joy" (17.1\% strongly agree, $40.9 \%$ agree, $\mathrm{M}=3.64$ ). Only $11.1 \%$ of respondents disagree with the item "WeChat plays a significant role for me to obtain information" ( $1.7 \%$ strongly disagree, $9.4 \%$ disagree, $\mathrm{M}=3.36)$. This is because that most of the undergraduate students are post-90's generation and growing up in the internet age, using mobile devices every day. They accept new technology very quickly and naturally. Within the atmosphere of friends and classmates created by WeChat, they pooled ideas and information, taking comfort from chatting, writing and reading.

\section{Conclusion}

In this changing information time, various technologies and services emerge in an endless stream. As the fastest growing mobile application in China, WeChat has becoming an indispensable part of campus life. Friends and relaxation, the key factors of undergraduate students' WeChat using, may be the same factors of information technologies acceptance among undergraduate students. On one hand, it is necessary for college students to release pressure and maintain the relationship between friends. On the other hand, it is important to let them understand that growth is the main task, and remind them to spend lots of time on learning instead of mobile apps.

\section{Funding}

Supported by “the Fundamental Research Funds for the Central Universities” SWU0909645.

\section{References}

Bai, H., \& Hao, J. J. (2013). Research on WeChat's Using in China High Education. The Chinese Journal of ICT in Education, 18.

Bai, X. Z., \& Guo, Q. (2014). WeChat: From Instant Message Tool to Platform System. Modern Communication (Journal of Communication University of China), 36.

CNNIC (2014). The 33rd Statistical Report on Internet Development in China. http://www.cnnic.net.cn/hlwfzyj/hlwxzbg/hlwtjbg/201403/t20140305_46240.htm

Gao, F., \& Zhang, Y. (2013). Analysis of WeChat on iPhone. 2nd International Symposium on Computer, Communication, Control and Automation, Atlantis Press. http://dx.doi.org/10.2991/3ca-13.2013.69

Karpinski, A. C., Kirschner, P. A., Ozer, I., Mellott, J. A., \& Ochwo, P. (2013). An Exploration of Social Networking Site 
Use, Multitasking, and Academic Performance among United States and European University Students. Computers in Human Behavior, 29, 1182-1192. http://dx.doi.org/10.1016/j.chb.2012.10.011

Li, Y. F. (2013). Ideological Education in University Based WeChat. China Educational Technology, 33.

Lin, K. Y., \& Lu, H. P. (2011). Why People Use Social Networking Sites: An Empirical Study Integrating Network Externalities and Motivation Theory. Computers in Human Behavior, 27, 1152-1161. http://dx.doi.org/10.1016/j.chb.2010.12.009

Tencent (2014). 2013 Annual Report. http://www.tencent.com/en-us/ir/reports.shtml

Xiao, L. H., \& Huang, J. H. (2013). Research on Information Service Mode of the Library Based on WeChat. Journal of Modern Information, 6, 13.

Yuan, L., Chen, X. H., \& Zhang, Y. L. (2012). Study on Blending Learning Based WeChat. China Educational Technology, 32.

Zhan, X., \& Yan, X. (2013). Study of WeChat's Impact on Interpersonal Communication. Modern Communication (Journal of Communication University of China), 35. 